\title{
The influence of passenger satisfaction on relationship formation in the South African domestic airline industry
}

\author{
C.F. De Meyer* \\ Research Unit for Economic and Management Sciences, \\ North-West University, Potchefstroom Campus, \\ Private Bag X6001, Potchefstroom and \\ Department of Marketing Management, University of Johannesburg, \\ Republic of South Africa \\ cfdemeyer@uj.ac.za \\ P.G. Mostert* \\ Research Unit for Economic and Management Sciences, \\ North-West University, Potchefstroom Campus, \\ Private Bag X6001, Potchefstroom, \\ Republic of South Africa \\ Received February 2010
}

\begin{abstract}
Customers are increasingly becoming aware of alternative offerings in the market place, and are thus more demanding in terms of their expectations pertaining to service delivery. As airlines in particular are vulnerable to competitors' offerings, they should offer passengers high levels of service and ensure that passengers are satisfied with their service offering in an effort to build long-term relationships. Building long-term relationships is important due to the financial and social benefits it holds to both the business and its customer. This study investigates whether passenger satisfaction influences whether or not passengers have formed a long-term relationship with the airline they fly with most often. Data was collected from South African domestic passengers departing from OR Tambo International Airport in Johannesburg by means of a convenience sample. Main findings from the study indicate that the majority of dissatisfied respondents have not formed a long-term relationship with the domestic airline, while satisfied respondents are more inclined to form a long-term relationship.
\end{abstract}

*To whom all correspondence should be addressed.

\section{Introduction}

Customers increasingly expect and demand high levels of service and satisfaction, resulting in businesses having to continuously provide high levels of customer service to satisfy customer needs (Jobber, 2004:462-463). As Aggarwal (2005), McClay and Whelan (2004), and Temporal and Trott (2001:20) explain, a strong customer service orientation must exist in the whole business before relationships can be formed with customers. It is by building and maintaining relationships that businesses can improve their success in a competitive business environment (Mullins, Walker, Boyd \& Larréché, 2005:11). It is for this reason that Rust and Chung (2006:570) suggest that it is important to research the connection between customer satisfaction and relationship formation in the service industry.

This article aims to determine whether passengers' satisfaction with South African domestic airlines influences the formation of relationships with the airlines they fly with. The South African domestic airline industry was chosen as domestic departures amount to approximately $70 \%$ of total departures, with more than 47 million passengers who flew domestically between April 2005 and March 2009 (ACSA, 2010). Although few studies on the effect of satisfaction on relationship formation in the airline industry have been conducted, none offered a South African perspective.

The remainder of this article firstly provides an insight into customer satisfaction and relationship formation through customer relationship management. The research methodology is then presented and the data analysis techniques are discussed followed by the results, implications and directions for future research.

\section{Literature review}

\section{Customer expectations}

Lovelock and Wirtz (2004:37-40), Grönroos (2004:106), and Gabbott and Hogg (1998:52) explain that since customers buy goods and services to meet specific needs, they will compare these offerings of various businesses to determine which offering will best suit and satisfy their needs. Customers will therefore spend more time comparing 
service offerings against what they expect to receive, especially if time, money and effort are involved when obtaining the service offering. Customers will be satisfied when they receive service levels that meet or exceed their expectations, but will not accept any lower service levels. In the airline industry, customer expectations could be as basic as wanting the flight to arrive on time, or could include expectations of a clean airplane, or in-flight refreshments and entertainment. Airlines need to know what customer needs and expectations are in order to exceed those expectations and so provide quality customer service and customer satisfaction.

\section{Customer satisfaction}

Customer satisfaction can for the purposes of this study be defined as a positive post-purchase assessment to which a business is able to meet customers' needs and/or exceed their expectations (Blackwell, Miniard \& Engel, 2006:742; Lamb, Hair \& McDaniel, 2005:10). Satisfaction can therefore be seen as how customers observe the services received in comparison with their previous experiences and expectations (Chau \& Kao, 2009:112; Torres \& Kline, 2006:290). Customers will evaluate their satisfaction with each service element provided by the business as well as their satisfaction with the overall service experience. This occurs since customers may place varying importance on certain service elements, which if not provided will cause dissatisfaction. Yet, it is suggested that if customers are not satisfied with the overall service experience, they will not repeat the purchase (Palmer, 2008:323). Ensuring customer satisfaction is essential for businesses to remain competitive (Kumar, Smart, Maddern \& Maull, 2008:176; Park, 2007:239) as customers who are satisfied are more likely return to the business as opposed to dissatisfied customers who would probably switch to a competitor (Fečiková, 2004:57). Yet, as Rhoades, Waguespack and Treudt (1998:306) explain, the general perception among customers is that airlines are more interested in cost-cutting than in improving service quality and customer service or satisfying customer needs.

\section{Customer relationship management}

Customer relationship management (CRM) arose from the need of businesses to keep up with the changing needs and demands of customers, markets and competitors (Maklan, Knox \& Ryals, 2007:221; Payne \& Frow, 2006:137-138). Although it is difficult to find a mutually agreed upon definition of CRM, possibly because of the fast evolution and changing nature thereof (McKenzie, 2000:41-42), numerous authors agree that the emphasis of CRM is on the building of customer relationships (Christopher, Payne \& Ballentyne, 2002:16; Gummesson, 2002:297; Ivens \& Shaw, 2002:98; Galbreath \& Rogers, 1999:162).

Li and Petrick (2008:237) and Jobber (2004:796-797) explain that through CRM, businesses are able to focus on existing customers rather than on attracting new customers. CRM furthermore aids businesses in retaining existing customers and improving the quality of the relationship between businesses and customers.
The benefits of CRM to the business include increased revenues and profit; reduced marketing costs; more effective decision-making, since the business understands customer needs better leading to increased customer satisfaction and retention; as well as the creation of a competitive advantage (Chalmeta, 2006:1016-1017; Torres \& Kline, 2006:293; Roh, Ahn \& Han, 2005:641; Jobber, 2004:797-798; Gummesson, 2002:310; McDonald, 2002:477; Temporal \& Trott, 2001:10). The benefits of CRM to customers include that by building long-term relationships with a business, customers build confidence in the quality of the product and service offering; and customers are treated as individuals with individual needs and are offered tailored services that meet their needs (Grönroos, 2004:36; Jobber, 2004:798-799; Temporal \& Trott, 2001:37).

Sheth and Uslay (2007:302), Zineldin and Philipson (2007:229), and Temporal and Trott (2001:20) emphasise that CRM and customer service are closely related, because CRM aims to build long-term relationships with customers by giving customers valued experiences through customer service which, in turn, aids in customer retention. Customer service is therefore an important part of building relationships for every business, and especially for service businesses, as each time a business does not offer quality customer service and satisfy customer needs, the relationship will be broken down even further. For this reason, CRM can affect customer satisfaction both positively and negatively.

\section{Customer satisfaction and CRM in the airline industry}

Anderson, Klein Pearo and Widener (2008:370), and Cheng, Chen and Chang (2008:487) state that the airline industry creates the perfect setting to study customer satisfaction and customer relationship management due to the number of service encounters passengers are involved in during their flight and since it is in the best interest of the airline to form a long-term relationship with customers. Atalik, Kampüsü and Turkey (2009:158), Li and Petrick (2008:239), and Boland, Morrison and O'Neill (2002:1-4) explain that CRM has become vital to the airline industry for airlines to gain a competitive advantage. A problem with the airline industry is that many airlines place an emphasis on cost reductions rather than considering customer service and customer satisfaction. Furthermore, many services provided by airlines are indistinguishable from one airline to the next, necessitating the need for airlines to find some other way of gaining a competitive advantage. CRM provides airlines with a basis of how to achieve long-term relationships and growth, while still achieving operational efficiency. Nadiri, Hussain, Ekiz and Erdoğan (2008:266), and Chang and Yeh (2002:166) state that due to the competitive nature of the airline industry, the only way in which airlines can remain competitive is by ensuring that customers are satisfied with the service encounter by exceeding customer expectations and by developing long-term relationships with these customers. 


\section{Problem statement}

Most studies previously conducted in the airline industry aimed to determine passenger expectations (see Chau \& Kao, 2009; Nejati, Nejati \& Shafaei, 2008; Fodness \& Murray, 2007; Pakdil \& Aydin, 2007; Prayag, 2007; Gilbert \& Wong, 2003; Chang \& Yeh, 2002; Pleger Bebko, 2000; Sultan \& Simpson, 2000). Although determining customer expectations is vital in providing quality service and satisfying customers (Cheng et al., 2008:489), none of these studies determined whether passengers were satisfied with the services provided by the airlines. Only studies such as Anderson et al. (2008), Park (2007) and Aksoy, Atilgan and Akinci (2003) concentrated on passenger satisfaction. The only studies that determined whether satisfaction has an effect on relationship formation in the airline industry included those conducted by Saha and Theingi (2009), Van Pham and Simpson (2006), and Bejou and Palmer (1998). No studies could be identified from a South African perspective that determine the effect of satisfaction on relationship formation within the domestic airline industry.

As Temporal and Trott (2001:20) explain, businesses need to build long-term relationships with customers by providing valued experiences through customer service and satisfying customer needs; however, as these authors state, every time a business does not offer quality services, relationships can be broken down further, which could possibly lead to a decrease in business profitability. Taking into account that no studies have been conducted on the influence of customer satisfaction on relationship formation from a South African domestic airline perspective, and that it was observed from literature that relationship formation is important for business profitability, the aim of this article is to determine whether the satisfaction levels of passengers flying with South African domestic passenger airlines influence the formation of relationships between the passenger and the domestic airline they most often fly with.

\section{Objectives and hypothesis}

The primary objective of this study is therefore to determine whether the satisfaction levels of passengers flying with domestic airlines in South Africa influence whether or not passengers form long-term relationships with the domestic airline they most often fly with. In order to achieve this primary objective, the following secondary objectives were set:

- To determine whether passengers are satisfied with the service elements offered by South African domestic passenger airlines;

- To determine whether or not passengers have formed relationships with South African domestic passenger airlines;

- To determine why passengers have or have not formed relationships with the South African domestic passenger airlines; and

- To identify whether passengers' satisfaction with the airlines' services influence whether or not they have formed a long-term relationship with the domestic airline.
Taking the above objectives into account, the following hypothesis was formulated:

$\mathrm{H}_{0}$ 1: Satisfied respondents have not formed a long-term relationship with the domestic airline they most often fly with.

\section{Research methodology}

The population for this study was determined as being all passengers departing from OR Tambo International Airport flying with any of South Africa's major domestic airlines (1Time, Kulula.com, Mango, Nationwide (this airline was still operational at the time of the study), South African Airlink, South African Airways and South African Express) to any domestic destination in South Africa. In this study, a nonprobability sampling method was used by means of convenience sampling. Trained fieldworkers intercepted passengers at OR Tambo International Airport after they had checked in for their flight. The fieldworkers asked passengers a screening question to determine how often they fly with the airline, as this information would be required to determine whether passengers have formed relationships or not. Only those passengers who flew twice or more with a specific domestic airline in the year preceding the survey were asked to complete the questionnaire.

The questionnaire used in a similar study by Gilbert and Wong (2003) concerning passenger expectations of airline services in Hong Kong was adapted for the purposes of this study. The questionnaire consisted of open- and closedended questions and were specifically aimed to determine which service elements respondents consider important when selecting an airline, whether they are satisfied with the services provided by the domestic airline they fly with most often and whether they had formed a long-term relationship with that domestic airline. The final section in the questionnaire aimed to gather demographic information about respondents. The questionnaire was pre-tested among 30 individuals who were randomly selected from the sample population. The pre-testing allowed for ambiguities in the questionnaire to be identified. Adjustments were made to the final questionnaire such as including a "not applicable" option as part of the scale as passengers may not have been exposed to certain service elements. The questionnaires were distributed over a two-week period at different times during the day so as to accommodate the various airlines' departure times. The fieldwork was conducted during normal travel times (not during peak and holiday periods) so as not the bias the data with passengers travelling on holidays and so ensure that only usual travellers were included in the sample. 405 questionnaires were distributed to passengers flying with various domestic airlines during the two-week period. Time constraints due to respondents having to board the airplane led to some questionnaires not being completely filled in. These questionnaires were discarded for the data analysis process, leading to 324 useable questionnaires (a realisation rate of $80 \%$ ).

The statistical analysis techniques used in this study included frequency analysis, cross-tabulations and effect sizes. Specifically tests for statistical and practical significance were conducted. According to Hardy and 
Bryman (2004:180) and Reid (1987:113), statistical significance illustrates whether a result obtained is significant and indicates the likelihood of whether a result occurred by chance. In this study, a Chi-square statistic with an exceedence probability of $<0,05$ is considered as being statistically significant. The problem with statistical significance is although it can indicate significance, it cannot determine the strength (importance) of the significance. For this reason, the w-value (effect size for associations in a cross-table) is used to determine whether associations exist between variables and whether these associations are practically significant and valid in terms of external measures (Steyn, 1999:I; Bagozzi, 1994:248). Steyn (1999:8) states that the effect size for the relationship in a cross-tabulation is interpreted by using the phicoefficient and provides the following guidelines for its interpretation:

- $\quad \mathrm{w}=0,1:$ small effect;

- $\quad w=0,3$ : medium effect; and

- $\quad \mathrm{w}=0,5$ : large effect, which is practically significant and indicates that associations between variables can be observed.

\section{Results}

\section{Sample profile}

From the results obtained from the demographic variables it can be discerned that more male respondents $(55,9 \%)$ than female respondents $(44,1 \%)$ participated in the study. The largest number of respondents was between the ages of twenty and forty $(65,4 \%)$. Concerning respondents' education, it was determined that nearly $32 \%(31,8 \%)$ of respondents had a diploma, $32,1 \%$ a university degree and a further $15,7 \%$ a post-graduate degree. Just over $70 \%$ of respondents either fly alone or with colleagues, with most respondents travelling for business reasons $(52,5 \%)$. Just under half $(49,4 \%)$ of the respondents make their own decision as to with which domestic airline to travel, while $24,7 \%$ of respondents' employers' business policy dictated which airline to use. Concerning the number of times respondents flew with the domestic airline within the 12 months preceding the study, it was found that $42,3 \%$ have flown once or twice, $39,2 \%$ flew three to six times, and $18,5 \%$ flew seven times or more with the airline they most often fly with.

\section{Customer satisfaction}

The questionnaire aimed to determine which of 26 listed service elements were important to respondents when selecting an airline and whether they were satisfied with the services provided by the domestic airline they fly with most often. The respondents were asked to rate their satisfaction with the 26 service elements on a five-point Likert scale, where $1=$ not satisfied at all, $2=$ not satisfied, $3=$ satisfied, $4=$ very satisfied and $5=$ not applicable. Table 1 presents the percentages of whether respondents were satisfied or dissatisfied with each of the service elements together with the mean score and standard deviation for each statement. "Not applicable" responses are omitted from the results portrayed in Table 1. For the purposes of determining the overall satisfaction or dissatisfaction levels of respondents for each statement, 1 and 2 on the Likert scale was combined to indicate whether respondents were "not satisfied" and 3 and 4 were combined to indicate whether respondents were "satisfied" with each service element.

From Table 1 it can be determined that service elements with the highest means, indicating that respondents were satisfied with the service element, included "you feel safe when you fly" with a mean of 3,32 (94,8\% of respondents were satisfied); "the ability to purchase tickets on-line" with a mean of 3,31 (87,9\% of respondents were satisfied); and "employees of the airline appear neat and tidy" with a mean of $3,26(92,6 \%$ of respondents indicating their satisfaction with this service element). The largest standard deviations (indicating a large deviation from the mean) could be observed in terms of whether the airline has comfortable waiting lounges (std. dev. $=1,00$ ); whether the flight departs and arrives on time (std. dev. $=0,91$ ) and the ability to check in on-line (std. dev. $=0,77$ ).

Service elements with the lowest means included "the airline has comfortable waiting lounges" with a mean of 2,38 and standard deviation of 1,00 (43,5\% of respondents were dissatisfied with the service element); "the flight departs and arrives on time" with a mean of 2,70 (38,0\% of respondents were dissatisfied with this service element); and "low prices of tickets" with a mean of 2,76 with $31,8 \%$ of respondents being dissatisfied with this service element.

Further analysis of these results was necessary to determine the influence of respondents' satisfaction on whether they formed a long-term relationship with the airline they most often fly with. In order to determine which respondents were satisfied with the overall service provided by the airlines, the average mean of the 26 service elements presented in Table 1 was calculated per respondent. All "not applicable" responses were coded as missing values that were ignored during the statistical calculation so that the mean would not be disproportionately distributed toward the higher value, resulting in an overstated mean. All respondents whose average mean scores were three and above were therefore deemed to be satisfied, whereas those with an average mean score of less than three were considered to be dissatisfied with the service offered by the airline. From this analysis, it was determined that 169 respondents $(52,2 \%)$ were satisfied and 155 respondents $(47,8 \%)$ were dissatisfied with the service elements provided by the domestic airline they fly with most often. Slightly more respondents were therefore considered to be satisfied with the service elements provided by the domestic airline, than those who were dissatisfied.

\section{Relationship formation}

Respondents were subsequently asked to indicate whether or not they have formed a long-term relationship with the airline they most often fly with. From the results it could be established that the majority of respondents $(56,2 \%)$ have not formed such a long-term relationship. 
Table 1: Respondents' satisfaction with service elements

\begin{tabular}{|c|c|c|c|c|}
\hline Service elements & $\begin{array}{c}\text { Satisfied } \\
(\%)\end{array}$ & $\begin{array}{c}\text { Dissatisfied } \\
(\%)\end{array}$ & Mean & Std. dev. \\
\hline Quality food and beverages are provided during the flight & 76,3 & 15,5 & 2,99 & 0,64 \\
\hline The domestic airline has convenient flight schedules & 83,0 & 16,0 & 3,09 & 0,64 \\
\hline The aircraft has comfortable interiors & 85,5 & 13,6 & 3,07 & 0,62 \\
\hline The airline has comfortable waiting lounges & 44,7 & 43,5 & 2,38 & 1,00 \\
\hline Employees of the airline appear neat and tidy & 92,6 & 4,9 & 3,26 & 0,58 \\
\hline The service is performed right the first time & 87,9 & 10,2 & 3,12 & 0,58 \\
\hline The promises made in advertising campaigns are kept & 78,7 & 18,5 & 2,96 & 0,64 \\
\hline Employees of the airline have knowledge to answer questions & 82,4 & 13,0 & 3,06 & 0,59 \\
\hline Employees of the airline offer you prompt service & 88,3 & 10,5 & 3,09 & 0,56 \\
\hline Employees of the airline understand your needs & 82,4 & 16,0 & 3,03 & 0,61 \\
\hline Employees of the airline are never too busy to respond to your requests or complaints & 81,5 & 16,3 & 3,00 & 0,61 \\
\hline Employees of the airline are consistently courteous & 85,8 & 13,0 & 3,07 & 0,57 \\
\hline Employees of the airline are always willing to help & 88,3 & 10,5 & 3,11 & 0,56 \\
\hline The flight departs and arrives on time & 60,8 & 38,0 & 2,70 & 0,91 \\
\hline Consistent ground services & 82,4 & 14,8 & 3,01 & 0,60 \\
\hline Consistent in-flight services & 90,1 & 8,6 & 3,10 & 0,52 \\
\hline You feel safe when you fly & 94,8 & 4,0 & 3,32 & 0,55 \\
\hline The ability to purchase tickets on-line & 87,9 & 6,1 & 3,31 & 0,62 \\
\hline The ability to track flights and schedules on-line & 76,9 & 15,2 & 3,11 & 0,73 \\
\hline The ability to check in on-line & 73,8 & 17,0 & 3,03 & 0,77 \\
\hline The airline offers additional services (e.g. air/accommodation/car hire packages) & 71,3 & 14,9 & 3,03 & 0,68 \\
\hline Airline has efficient check-in services & 83,0 & 14,2 & 3,09 & 0,63 \\
\hline The airline has sufficient check-in services & 77,5 & 20,3 & 2,97 & 0,66 \\
\hline Airline has efficient baggage handling services & 81,5 & 15,8 & 3,00 & 0,63 \\
\hline Airline has sufficient baggage handling services & 80,5 & 17,6 & 2,97 & 0,60 \\
\hline Low prices of tickets & 67,0 & 31,8 & 2,76 & 0,73 \\
\hline
\end{tabular}

When asked to specify why they have or have not formed long-term relationships with the airlines they most often fly with, respondents listed a number of responses by means of open-ended questions. Table 2 presents the reasons why respondents had formed a long-term relationship, while Table 3 indicates the reasons why respondents who have not formed a long-term relationship, did not do so.

From Table 2 it can be discerned that most respondents have formed a long-term relationship with the domestic airline due to the services $(39.4 \%)$ and loyalty programme (25.4\%) offered by the domestic airline they most often fly with.

The main reasons respondents provided for not forming a long-term relationship with the domestic airline, as indicated in Table 3, include that the respondent does not want to form a relationship $(30,2 \%)$; they do not feel that they are important enough to the domestic airline to form a long-term relationship $(21,4 \%)$; and the high prices of tickets $(19,2 \%)$.

\section{Effect of satisfaction on relationship formation}

Table 4 presents the results from a cross-tabulation of respondents' satisfaction and whether they have formed a long-term relationship with the domestic airline they fly with most often (Tables $4 \mathrm{a}$ and $4 \mathrm{~b}$ in the Annexure present the detailed statistical exposition associated with this crosstabulation). In Table 4 the row percentages are listed.

From Table 4 it can be determined that although almost half of the respondents $(49,7 \%)$ who indicated they were satisfied have formed a relationship with the domestic airline they fly with most often, the majority of dissatisfied respondents $(62,6 \%)$ have not formed a relationship. In order to determine whether an association exists between these variables, a Chi-square test was conducted. The test realised an exceedence probability of $\mathrm{p}=0,035$, indicating that a statistically significant association between the variables can be observed. Hypothesis $\mathrm{H}_{0} 1$ can therefore be rejected as there is a statistically significant association between respondents' satisfaction with the airlines' overall service and whether they have formed a long-term relationship with the airline they fly with most often. It was, however, decided to determine the effect size of the association. From Table $4 \mathrm{~b}$ it can be noticed that a small effect can be observed as the phi-coefficient realised a value of 0,124 , implying that the result is not practically significant.

\section{Summary and managerial implications}

From the literature review it was established that it is essential for businesses to ensure customer satisfaction if they want to remain competitive (Kumar et al., 2008:176; Park, 2007:239), as customers who are satisfied are more likely to return to the business as opposed to dissatisfied customers who would probably switch to a competitor (Fečiková, 2004:57).

Results from this study indicated that slightly more respondents were satisfied with the overall service provided by the domestic airline they fly with most often than those who were dissatisfied. This finding should be alarming to airlines competing in the domestic airline industry when considering the number of competitors in the industry as well as the relatively low switching costs associated with moving from one airline to one of its competitors. 
Table 2: Reasons for forming a long-term relationship with the domestic airline

\begin{tabular}{|c|c|c|}
\hline Reason & $\mathbf{F}$ & $\%$ \\
\hline Service & 56 & 39,4 \\
\hline Loyalty programme & 36 & 25,4 \\
\hline Prices offered by airline & 16 & 11,3 \\
\hline Airline provides the best package & 15 & 10,6 \\
\hline Availability of flights & 12 & 8,5 \\
\hline Airline is a trusted brand & 5 & 3,5 \\
\hline
\end{tabular}

Table 3: Reasons for not forming a long-term relationship with the domestic airline

\begin{tabular}{|c|c|c|}
\hline Reason & $\mathbf{F}$ & $\%$ \\
\hline Respondent does not want to form a relationship & 55 & 30,2 \\
\hline Respondent does not feel important enough to the airline & 39 & 21,4 \\
\hline High prices of tickets charged by the airline & 35 & 19,2 \\
\hline Poor service & 20 & 11,0 \\
\hline Lack of available flights & 14 & 7,7 \\
\hline Fly airline due to business policy (have no choice) & 10 & 5,5 \\
\hline No real difference between airlines & 5 & 2,8 \\
\hline
\end{tabular}

Table 4: Respondents' satisfaction with the airlines and whether they have formed a long-term relationship with the airlines

\begin{tabular}{|c|c|c|c|c|}
\hline & & \multirow{2}{*}{\multicolumn{2}{|c|}{ Whether long-term relationship was formed }} & \multirow{3}{*}{ Total } \\
\hline & & & & \\
\hline & & Have formed a relationship & Have not formed a relationship & \\
\hline \multirow{2}{*}{$\begin{array}{l}\text { Satisfaction with } \\
\text { airlines }\end{array}$} & Satisfied & $\begin{array}{l}84 \\
49,7 \%\end{array}$ & $\begin{array}{l}85 \\
50.3 \%\end{array}$ & $\begin{array}{c}169 \\
100 \%\end{array}$ \\
\hline & Dissatisfied & $\begin{array}{l}58 \\
37,4 \%\end{array}$ & $\begin{array}{l}97 \\
62.6 \%\end{array}$ & $\begin{array}{c}155 \\
100 \%\end{array}$ \\
\hline \multicolumn{2}{|l|}{ Total } & $\begin{array}{l}142 \\
43.8 \%\end{array}$ & $\begin{array}{l}182 \\
56,2 \%\end{array}$ & $\begin{array}{c}324 \\
100 \%\end{array}$ \\
\hline
\end{tabular}

Pertaining to the forming of relationships with the airline, results indicated that the majority of respondents have not formed a long-term relationship with the domestic airline they fly with most often which could influence the longterm sustainability of the airline. Reasons for not forming a long-term relationship include that respondents did not want to form such a relationship and that they did not feel as if they were important enough to the domestic airline in order to form a long-term relationship. Respondents who did form a long-term relationship indicated they had done so because of the service and loyalty programmes offered by the airline. Airlines should therefore determine which customers want to form a long-term relationship with them and provide those customers with high quality services and a loyalty programme that will meet their individual needs.

Concerning the main purpose of this article, namely to determine whether passenger satisfaction influences the formation of long-term relationships in the South African domestic passenger airline industry, it was found that almost half of the respondents $(49,7 \%)$ who were satisfied have formed a long-term relationship with the domestic airline they fly with most often. Further statistical analysis indicated that although passenger satisfaction does influence the formation of long-term relationships with domestic airlines, this result is of little practical significance. Despite this conclusion from the statistical analysis, it should be emphasised that the majority of respondents $(62,6 \%)$ who were dissatisfied with the airlines' service did not form a long-term relationship with the airline. This finding could therefore support the suggestion that by not offering satisfactory service to their customers, airlines will find it difficult to build long-term relationships with them.
The findings from this study therefore suggest that by not satisfying customers by means of effective customer service, customers will be less inclined to form a long-term relationship. For this reason, it can be recommended that domestic passenger airlines should improve the services offered to their passengers in an effort to increase customer satisfaction and thereby encourage forming long-term relationship with the domestic airline.

\section{Limitations and future research}

A limitation experienced in this study was a lack of literature on the South African airline industry. This required that literature from the airline industry of other countries or other industries had to be consulted. Furthermore, a convenience survey method had to be used since domestic airlines were not prepared to provide access to their passenger database. Finally, problems were experienced in obtaining permission to distribute the questionnaire at OR Tambo International Airport. Although each domestic airline was contacted to determine whether questionnaires could be distributed on their flights, no domestic airline granted permission for this. Although permission was originally granted by Airports Company of South Africa (ACSA) to distribute questionnaires in the departure lounge of OR Tambo International Airport, security measures meant that the time span, as well as the locality where questionnaires could be distributed, had to be revised.

Possible future research areas could include that a similar study be conducted on international airlines, since passengers flying domestically and those travelling on international flights may require different levels of service 
and find other service elements more important. This could indicate how airlines' domestic and international strategies need to be adapted or re-designed. Furthermore, studies could be conducted into which elements need to be provided by airlines so that passengers will want to form long-term relationships with them.

\section{Contribution of the study}

This study aids in providing an understanding of the link between customer satisfaction and relationship formation within the airline industry in South Africa which has, to date, been limited. The study adds to the current knowledge of the South African airline industry and customer expectations of domestic airlines which could aid airlines in developing more effective service and CRM strategies. By taking the results of this study into account, South African airlines should realise the importance of improving customer satisfaction levels in order to remain competitive in an increasingly competitive industry.

\section{References}

ACSA (Airports Company of South Africa). 2010. 'Passenger statistics'. [online] URL: http://www.acsa.co.za/home.asp?pid=100.

Aggarwal, A. 2005. 'CSM comes first CRM later'. [online] URL: http://www.etretailbiz.com/feb05/cStory02 htm

Aksoy, S., Atilgan, E. \& Akinci, S. 2003. 'Airline services marketing by domestic and foreign firms: Differences from the customers' viewpoint', Journal of Air Transport Management, 9: 343-351.

Anderson, S., Klein Pearo, L. \& Widener, S.K. 2008. 'Linking customer satisfaction to the service concept and customer characteristics', Journal of Service Research, 10(4): 365-381.

Atalik, O., Kampüsü, I.E. \& Turkey, E. 2009. 'A study to determine the effects of customer value on customer loyalty in airline companies operating: Case of Turkish air travellers', International Journal of Business and Management, 4(6): 154-162.

Bagozzi, R.P. (ed.). 1994. Principles of marketing research. Cambridge, Massachusetts: Blackwell Publishers.

Bejou, D. \& Palmer, A. 1998. 'Service failure and loyalty: An exploratory empirical study of airline customers', Journal of Services Marketing, 12(1): 7-22.

Blackwell, R.D., Miniard, P.W. \& Engel, J.F. 2006. Consumer behavior. $10^{\text {th }}$ Edition. Mason, Ohio: Thomson South-Western..

Boland, D., Morrison, D. \& O'Neill, S. 2002. The future of CRM in the airline industry: a new paradigm for customer management. Somers, New York: IBM Institute for Business Value.
Chalmeta, R. 2006. 'Methodology for customer relationship management', The Journal of Systems and Software, 79(7): 1015-1024.

Chang, Y. \& Yeh, C. 2002. 'A survey analysis of service quality for domestic airlines', European Journal of Operational Research, 139: 166-177.

Chau, V.S. \& Kao, Y. 2009. 'Bridge over troubled water or long and winding road: Gap 5 in airline service quality performance measures', Managing Service Quality, 19(1): 106-134.

Cheng, J., Chen, F. \& Chang, Y. 2008. 'Airline relationship quality: an examination of Taiwanese passengers', Tourism Management, 29: 487-499.

Christopher, M., Payne, A. \& Ballantyne, D. 2002. Relationship marketing: Creating shareholder value. Oxford: Butterworth-Heinemann.

Fečiková, I. 2004. 'An index method for measurement of customer satisfaction', The TQM Magazine, 16(1): 57-66.

Fodness, D. \& Murray, B. 2007. 'Passengers' expectations of airport service quality', Journal of Services Marketing, 21(7): 492-506.

Gabbott, M. \& Hogg, G. 1998. Consumers and services. New York: Wiley.

Galbreath, J. \& Rogers, T. 1999. 'Customer relationship leadership: A leadership and motivation model for the twenty-first century business', The TQM Magazine, 11(3): 161-171.

Gilbert, D. \& Wong, R.K.C. 2003. 'Passenger expectations and airline services: A Hong Kong based study', Tourism Management, 24: 519-532.

Grönroos, C. 2004. Service management and marketing: A customer relationship management approach. $2^{\text {nd }}$ Edition. Chichester: Wiley.

Gummesson, E. 2002. Total relationship marketing: Marketing management, relationship strategy and CRM approaches for the network economy. $2^{\text {nd }}$ Edition. Oxford: Butterworth-Heinemann.

Hardy, M. \& Bryman, A. (eds.) 2004. Handbook of data analysis. London: Sage.

Ivens, J. \& Shaw, C. 2002. Building great customer experiences. New York: Palgrave.

Jobber, D. 2004. Principles and practice of marketing. $4^{\text {th }}$ Edition. London: McGraw-Hill.

Kumar, V., Smart, P.A., Maddern, H. \& Maull, R.S. 2008. 'Alternative perspectives on service quality and customer satisfaction: The role of BPM', International Journal of Service Industry Management, 19(2):176-187. 
Lamb, C.W., Hair, J.F. \& McDaniel, C. 2005. Essentials of marketing. $4^{\text {th }}$ Edition. Mason, Ohio: Thomson SouthWestern.

Li, X. \& Petrick, J.F. 2008. 'Tourism marketing in an era of paradigm shift', Journal of Travel Research, 46(3): 235244.

Lovelock, C. \& Wirtz, J. 2004. Services marketing: people, technology, strategy. $5^{\text {th }}$ Edition. Upper Saddle River, New Jersey: Pearson Prentice Hall.

Maklan, S., Knox, S. \& Ryals, L. 2007. 'New trends in innovation and customer relationship management: A challenge for market research', International Journal of Market Research, 50(2): 221-240.

McClay, L. \& Whelan, D. 2004. 'A view from the top: a unified view of your customers'. [online] URL: http://www.tmenet.com/cis/0904/CRM.htm.

McDonald, M. 2002. Marketing plans: How to prepare them, how to use them. $5^{\text {th }}$ Edition. Oxford: ButterworthHeinemann.

McKenzie, R. 2000. The relationship-based enterprise: Powering business success through customer relationship management. Toronto: McGraw-Hill.

Mullins, J.W., Walker, O.C., Boyd, H.W. \& Larréché, J. 2005. Marketing management: A strategic decision-making approach. $5^{\text {th }}$ Edition. Boston, Massachusetts: McGraw-Hill.

Nadiri, H., Hussain, K., Ekiz, E.H. \& Erdoğan, S. 2008. 'An investigation on the factors influencing passengers' loyalty in the North Cyprus national airline', The TQM Journal, 20(3): $265-280$.

Nejati, Mehran., Nejati, Mustafa \& Shafaei, A. 2008. 'Ranking airlines' service quality factors using a fuzzy approach: study of the Iranian society.', International Journal of Quality and Reliability Management, 26(3): 247260.

Pakdil, F. \& Aydin, O. 2007. 'Expectations and perceptions in airline services: An analysis using weighted SERVQUAL scores', Journal of Air Transport Management, 13: 229-237.

Palmer, A. 2008. Principles of services marketing. $5^{\text {th }}$ Edition. Boston, Massachusetts: McGraw-Hill.

Park, J. 2007. 'Passenger perceptions of service quality: Korean and Australian case studies', Journal of Air Transport Management, 13: 238-242.

Payne, A. \& Frow, P. 2006. 'Customer relationship management: From strategy to implementation', Journal of Marketing Management, 22: 135-168.
Pleger Bebko, C. 2000. 'Service intangibility and its impact on consumer expectations of service quality', Journal of Services Marketing, 14(1): 9-26.

Prayag, G. 2007. 'Assessing international tourists' perceptions of service quality at Air Mauritius', International Journal of Quality and Reliability Management, 24(5): 492-514.

Reid, S. 1987. Working with statistics: An introduction to quantitative methods for social scientists. Oxford: Polity Press.

Rhoades, D.W., Waguespack, B. \& Treudt, E. 1998. 'Service quality in the US airline industry: Progress and problems', Managing Service Quality, 8(5): 306-311.

Roh, T.H., Ahn, C.K. \& Han, I. 2005. 'The priority factor model for customer relationship management system success', Expert Systems with Application, 28(4): 641-654.

Rust, R.T. \& Chung, T.S. 2006. 'Marketing models of service and relationships', Marketing Science, 25(6): 560580 .

Saha, G.C. \& Theingi, H. 2009. 'Service quality, satisfaction, and behavioural intentions: A study of low-cost airline carriers in Thailand', Managing Service Quality, 19(3): $350-372$.

Sheth, J.N. \& Uslay, C. 2007. 'Implications of the revised definition of marketing: From exchange to value creation', Journal of Public Policy and Marketing, 26(2): 302-307.

Steyn, H.S. 1999. Praktiese beduidendheid: Die gebruik van effekgroottes. Potchefstroom: Publikasiebeheerkomitee Potchefstroomse Universiteit vir CHO.

Sultan, F. \& Simpson, M.C. 2000. 'International service variants: Airline passenger expectations and perceptions of service quality', Journal of Services Marketing, 14(3): 188216.

Temporal, P. \& Trott, M. 2001. Romancing the customer: Maximising brand value through powerful relationship management. New York: Wiley.

Torres, E.N. \& Kline, S. 2006. 'From satisfaction to delight: A model for the hotel industry', International Journal of Contemporary Hospitality Management, 18(4):290-301.

Van Pham, K. \& Simpson, M. 2006. 'The impact of frequency of use on service quality expectations: An empirical study of Trans-Atlantic airline passengers', The Journal of American Academy of Business, 10(1): 1-6.

Zineldin, M. \& Philipson, S. 2007. 'Kotler and Borden are not dead: Myth of relationship marketing and truth of the 4Ps', Journal of Consumer Marketing, 24(4): 229-241. 


\section{Annexure}

Table 4a: Respondents' satisfaction with the airlines' service and whether they have formed a long-term relationship with the airlines

Chi-Square Tests

\begin{tabular}{|l|r|r|r|r|c|}
\hline & Value & Df & $\begin{array}{c}\text { Asymp. Sig. (2- } \\
\text { sided) }\end{array}$ & $\begin{array}{c}\text { Exact Sig. (2- } \\
\text { Sided) }\end{array}$ & $\begin{array}{c}\text { Exact Sig. (1- } \\
\text { sided) }\end{array}$ \\
\hline Pearson Chi-square & $4.956^{\mathrm{a}}$ & 1 & .026 & & \\
\hline Continuity Correction $^{\mathrm{b}}$ & 4.470 & 1 & .035 & & \\
\hline Likelihood ratio & 4.974 & 1 & .026 & & .033 \\
\hline Fisher's Exact Test & & & & & \\
\hline Linear-by-Linear Association & 4.941 & 1 & & & \\
\hline N of Valid Cases & 324 & & & & \\
\hline
\end{tabular}

a. 0 cells $(.0 \%)$ have expected count less than 5 . The minimum expected count is 67.93

b. Computed only for a $2 \times 2$ table

Table 4b: Respondents' satisfaction with the airlines' service and whether they have formed a long-term relationship with the airlines

Symmetric Measures

\begin{tabular}{|c|c|c|c|}
\hline & & Value & Approx. Sig. \\
\hline \multirow[t]{4}{*}{ Nominal by Nominal } & Phi & .124 & .026 \\
\hline & Cramer's V & .124 & .026 \\
\hline & Contingency Coefficient & .123 & .026 \\
\hline & N of Valid Cases & 324 & \\
\hline
\end{tabular}


